\title{
SARS-CoV-2: a view on its origin, transmission, genetic characteristics and pathogenicity
}

\author{
SARS-CoV-2: uma visão sobre sua origem, transmissão, características genéticas e \\ patogenicidade
}

\author{
SARS-CoV-2: una visión sobre su origen, transmisión, características genéticas y \\ patogenicidad
}

Kassyo Lenno Sousa Dantas ${ }^{1 *}$, Wilian Reis Rosário ${ }^{1}$, Alice Gabrielly Landim Lima1, Antonio Ycaro Rodrigues Lucena1, Thallysson Jose Dourado de Sousa1, Jeferson Noslen Casarin², Fabíola Santos Lima de Oliveira $^{3}$, Milena Sousa Freitas ${ }^{1}$, Cristiane Santos Silva e Silva Figueiredo ${ }^{1}$, Domingos Magno Santos Pereira ${ }^{1}$.

\begin{abstract}
Objective: To describe the origin, transmission, morphological and genetic characteristics of SARS-CoV-2 and its pathogenicity mechanisms. Bibliographic review: At the end of December 2019, health centers in Wuhan, Hubei-China province, observed several cases of pneumonia of unknown origin, associated with a new etiologic agent, a virus, with a similar, but distinct, genomic sequence of SARS-CoV and MERS-CoV, named as severe acute respiratory syndrome coronavirus 2 (SARS-CoV-2). The most common symptoms at the beginning of the infection are fever, cough, fatigue, olfactory and taste disorders; on the other hand, severe cases include pulmonary impairment and hypoxia. Currently, there are no antiviral agents with proven clinical efficacy and vaccination occurs in slow steps in most countries, with symptomatic treatment and life support still being the main therapeutic interventions available. Final considerations: SARS-CoV-2 presents itself as one of the biggest public health problems in the world nowadays. The search for new drugs to treat COVID19 is constant, however, so far no new drug is available for use with $100 \%$ proven clinical efficacy.
\end{abstract}

Keywords: SARS-CoV-2, COVID-19, Pathophysiology, Immune, Response.

\section{RESUMO}

Objetivo: Descrever a origem, modo de transmissão e as características morfológicas e genéticas do SARSCoV-2 e seus mecanismos de patogenicidade. Revisão bibliográfica: No final de dezembro de 2019, centros de saúde em Wuhan, província de Hubei-China, observaram vários casos de pneumonia de origem desconhecida, associados a um novo agente etiológico, um vírus, de sequência genômica com composição semelhante, mas distinto de SARS-CoV e MERS-CoV, nomeado como coronavírus 2 da síndrome respiratória aguda grave (SARS-CoV-2). Os sintomas mais comuns no início da infecção são febre, tosse, fadiga, distúrbios olfatórios e gustativos; por outro lado, sintomas mais graves incluem o comprometimento pulmonar e quadros graves de hipóxia. Não há atualmente nenhum agente antiviral com eficácia clínica comprovada e a vacinação ocorrre em passos lentos na maioria dos países, sendo o tratamento sintomático e suporte a vida ainda as principais intervenções terapêuticas disponíveis. Considerações finais: SARS-CoV-2 se apresenta como um dos maiores problemas de saúde pública em todo o mundo atualmente. A busca por novas drogas para tratar a COVID-19 é constante, no entanto, até o momento nenhum novo fármaco está disponível para uso com eficácia clínica $100 \%$ comprovada.

Palavras-chave: SARS-CoV-2, COVID-19, Fisiopatologia, Resposta, Imune.

\footnotetext{
1 Universidade CEUMA (UNICEUMA), Imperatriz - MA. *E-mail: kassyolenno@outlook.com

2 Centro Brasileiro de Análises Clínicas (CEBRAC), Imperatriz - MA.

${ }^{3}$ Clínica Innovant: Estética Avançada Integrativa (CIEAI), Imperatriz - MA.
} 


\section{RESUMEN}

Objetivo: Describir el origen, modo de transmisión, características morfológicas y genéticas del SARS-CoV2 y sus mecanismos de patogenicidad. Revisión bibliográfica: A fines de diciembre de 2019, los centros de salud de Wuhan, provincia de Hubei-China, observaron varios casos de neumonía de origen desconocido, asociados a un nuevo agente etiológico, un virus, de secuencia genómica de composición similar, pero distinto al SARS-CoV y MERS. -CoV, denominado coronavirus 2 del síndrome respiratorio agudo severo (SARS-CoV2). Los síntomas más comunes al inicio de la infección son fiebre, tos, fatiga, alteraciones del olfato y del gusto; por otro lado, los síntomas más severos incluyen deterioro pulmonar e hipoxia severa. Actualmente, no existen agentes antivirales con eficacia clínica probada y la vacunación se produce en pasos lentos en la mayoría de los países, siendo el tratamiento sintomático y el soporte vital las principales intervenciones terapéuticas disponibles. Consideraciones finales: EI SARS-CoV-2 se presenta como uno de los mayores problemas de salud pública del mundo. El tratamiento aún se basa en el soporte vital, requiriendo terapias alternativas y se deben desarrollar nuevas intervenciones, como la producción de vacunas y medidas terapéuticas específicas.

Palabras clave: SARS-CoV-2, COVID-19, Fisiopatología, Respuesta, Inmune.

\section{INTRODUCTION}

Coronaviruses (VOCs), named because of the the shape of their spikes resemble a crown (from the Latin: corona $=$ crown), are positive-sense RNA viruses belonging to the Coronavidae family of the order Nidovirales. Based on their genomic structure, they have four main subgroups; alpha, beta, gamma and delta. Alphas and beta-coronaviruses infect only mammals, presenting, in humans, most of the time, respiratory symptoms; and gastroenteritis in other animals (ZHOU P, et al., 2020; WU F, et al., 2020).

Until December (2019), four human coronavirus genotypes were associated with infections: Human coronavirus NL63 (HCoV-NL63), human coronavirus 229E (HCoV-229E), human coronavirus OC43 (HCoVOC43) and human coronavirus HKU1 (HKU1), causing mild symptoms of cold, such as fatigue, fever and malaise in immunocompetent individuals. In 2002-2003, these viruses caused an epidemic of Severe Acute Respiratory Syndrome (SARS) in Guangdong-China, with a mortality rate of $10 \%$. In 2012, the MERS-CoV (Coronavirus of the Middle East Respiratory Syndrome) was responsible for endemic outbreaks in the countries of the Middle East, reaching a mortality rate of 37\%. In late December 2019, researchers from Wuhan City, Hubei Province, China, observed several patients with cases of pneumonia of a previously unknown origin, which spread rapidly (LIU J, et al., 2020; ZHOU P, et al., 2020; WIT E, et al., 2016).

From the sequential analysis of isolates from the first patients, the cases were associated with a new etiological agent, a virus of genomic sequence similar to coronaviruses related to human infections, but with different molecular characteristics from SARS-CoV and MERS-CoV. Shortly thereafter, this new etiologic agent would be classified as a new coronavirus member of the betacoronavirus subgroup, appointed by the International Virus Taxonomy Committee as coronavirus 2 of the Severe Acute Respiratory Syndrome (SARSCoV-2), a new pathogen with high transmissibility power and that caught the attention of the world health organization (WHO) and the whole world (RABI FA, et al., 2020).

After the first infections, on January 30, 2020, WHO declared the SARS-CoV-2 pandemic, a global and emergency public health problem. As it is a new human pathogen virus, several aspects of the pathogenesis were not clarified, as well as there was (and still is not) an effective treatment for this virus, which aggravated this new health crisis of worldwide proportions. The absence of drugs and vaccines has caused the whole world to be quarantined and socially isolated, affecting various social aspects around the world (RABI FA, et al., 2020).

Therefore, due to the need to understand more about this virus, this article aims to describe the possible origin, mode of transmission and the morphological and genetic characteristics of SARS-CoV-2, as well as its mechanisms of pathogenicity and main proposed therapeutic measures. 


\section{BIBLIOGRAPHIC REVIEW}

\section{Viral Morphology and Structure - SARS-CoV-2}

The viral particle is spherical in shape with a diameter of approximately 60 to $140 \mathrm{~nm}$ and peaks between 8 to $12 \mathrm{~nm}$ in length. The viral genetic material $\left(\mathrm{RNA}^{+}\right)$is surrounded and protected by a nucleocapsid and a lipoprotein envelope. The nucleocapsid and the viral genome are associated with the nucleoprotein $\mathrm{N}$. On the surface of the virions are structural proteins, including: Spike protein (S), membrane protein (M) and envelope protein $(E)$; in addition to other accessory proteins: Hemagglutinin esterase (HE), protein 3 and protein 7 (LI G, et al., 2020; RABAAN AA, et al., 2020; ZENG J, et al., 2020).

The main functions of these viral proteins are extend from the binding of the virus to the receptors present in the cells to assembly and viral release. Protein $S$ facilitates the binding of the virus to host cell receptors; the protein $\mathrm{M}$ helps to maintain the curvature of the membrane and the union with the nucleocapsid; protein $\mathrm{E}$ mediates the assembly and release of new viral particles; protein $\mathrm{N}$ makes up the nucleocapsid by binding to viral genetic material. In addition, the accessory protein HE is found isolated and may be associated with the entry of the virus into the cell, since it assists in the fixation of viral particles when they interact with cell proteins (RABAAN AA, et al., 2020). An illustration of the structure of Sars-CoV-2 can be seen in Figure 1 (made with the software: Microsoft Publisher).

Figure 1 - Morphology and structure.

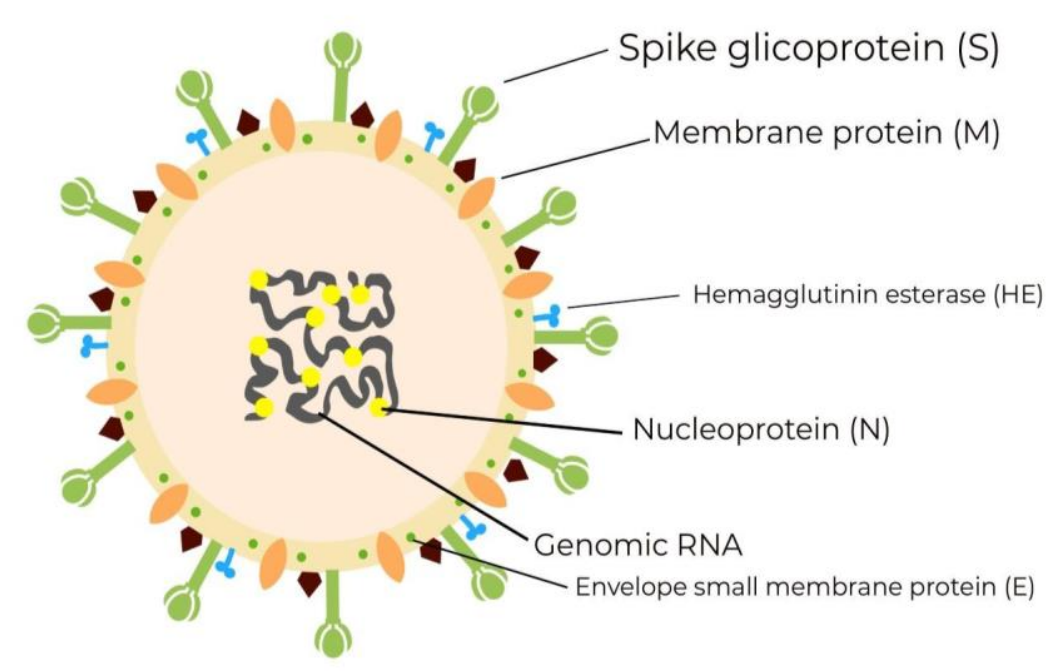

Source: Dantas KLS, et al., 2021.

\section{Genetic Material - SARS-CoV-2}

Its genome is composed of a single strand of positive polarity RNA (ssRNA+) with approximately 30.000 base pairs. The structure of the RNA resembles a messenger RNA (mRNA) from eukaryotic cells, due to a methylated termination at the $5^{\prime}$ end and the presence of the polyadenylated tail (poly-A) at the $3^{\prime}$ end, assuming a certain similarity with host cell mRNAs, differentiating itself by presenting at least six coronavirusrelated open reading phases (ORFs) (LI G, et al., 2020; RABAAN AA, et al., 2020).

The SARS-CoV-2 genome is divided into three parts, the first two (close to the $5^{\prime}$ end) responsible for encoding genes related to viral replication (formed by two open reading frames, ORF 1a and ORF $1 b$ ). These genes are responsible for the transcription of mRNA that will be translated into two polypeptides (ppla and pplab), which are subsequently cleaved by proteases, originating 16 non-structural proteins (NSPs), responsible for assisting the replication of the viral particle genome and subgenomic mRNA (sgRNA) transcription. The third part of the genome of the new COV is responsible for the production of structural proteins, described previously (CHEN Y, et al., 2020). 


\section{Transmission and Symptoms}

It is mainly transmitted by contact with droplets expelled by sneezing or coughing of infected patients. Transmission also occurs through contact with contaminated objects and surfaces when taking the hands in the eyes, nose or mouth. Symptoms of the infection appear after their incubation period (5-7 days), depending on the age and condition of the patient's immune system. SARS-CoV-2 infects different profiles of people and can act differently according to each person's genetics (BRITTO DBLA, et al., 2020; YANG X, et al., 2020).

The most common symptoms at the beginning of the disease are fever, dry cough and tiredness; the less common ones include general pain, sore throat, diarrhea, conjunctivitis, headache, loss of smell or taste and skin rashes; yet, severe cases are usually associated with the following symptoms: difficulty in breathing or shortness of breath, pain or pressure in the chest and loss of speech and movement. The most common cause of death from COVID is hypoxia (shortness of breath), caused by lung inflammation (CALISHER C, et al., 2020; BRITTO DBLA, et al., 2020).

\section{Risk and Aggravation Factors}

Risk groups for the worsening of COVID-19 are people with chronic diseases, hypertension, diabetes, chronic obstructive pulmonary disease, asthma; and also individuals who smoke, the elderly, postpartum women, pregnant women and children under 5 years. Some diseases can contribute to a higher mortality from SARS-CoV-2, such as thalassemia and sickle cell anemia. Furthermore, immunocompromised patients (HIV infection, use of immunosuppressive drugs...) are also part of the risk group (PIVA S, et al., 2020; XAVIER AR, et al., 2020).

Obese people tend to have circulation problems, which can also contribute to the worsening of COVID-19, since these people are more predisposed to the development of thrombi and SARS-CoV-2 has already been shown to be a thrombogenic virus. In the elderly, immunosenescence stands out as the main risk factor for this population. It is also important to emphasize that the indigenous and prison population also need special care, due to the vulnerability of these groups to the disease (PIVA S, et al., 2020; XAVIER AR, et al., 2020).

\section{Virus Entry into the Host Cell and Replication Process}

For the infection to start, the binding between the spike protein (also called S-glycoprotein) and the cellular receptor for angiotensin-converting enzyme 2 (ACE2) is required. The expression of receptors for ACE2 in several organs is identified as the main mechanism of penetration of the coronavirus in the blood stream (infection route: mucosal vessels) and in the lungs (causing pulmonary inflammation), in addition to the involvement of other organs (JIN Y, et al., 2020; LI X, et al., 2020).

ACE2 is usually higher expressed in the type 2 of alveolar cells of the lung, which is why it is the organ most affected by the disease. It is known that viral spike proteins are divided into two subunits ( $\mathrm{S} 1$ and $\mathrm{S} 2$ ), the $\mathrm{S} 1$ terminal interacts with the ACE2 receptor (receptor-binding domain: RBD) while S2 terminal promotes the fusion of the viral envelope with host cell membrane (GUO YR, et al., 2020; PASTRIAN SG, 2020; LI G, et al., 2020).

For the fusion to be successful, protein $S$ must be cleaved, a step carried out by the transmembrane protease serine 2 (TMPRSS2) and/or by the B and L cathepsins (another type of protease) present in the endosomes of various cells, aiding the separation between the RBD portion of the S1 subunit (of the virus $S$ protein) with the ACE2 receptor, resulting in complete fusion of the cell membrane with the viral envelope, allowing the entry of the virus nucleocapsid into the cytoplasm, with subsequent stripping of the viral RNA and beginning of the replication process (GUO YR, et al., 2020; PASTRIAN SG, 2020; LI G, et al., 2020).

The entry of the virus can occur by endocytosis (formation of endosomes), in this case, dependent of the action of cathepsins B/L proteases (Figure 2A); or by direct fusion of the envelope with the cytoplasmic membrane, a process mediated by the TMPRSS2 (Figure 2B). In the absence of TMPRSS2, the virus enters only through the formation of endosomes. In both cases, the spike protein must be cleaved in order for the 
process to occur (GUO YR, et al., 2020; PASTRIAN SG, 2020; LI G, et al., 2020). Figure 2 (software: Microsoft Publisher) presents an overview of the forms of viral penetration in the host's cells, with subsequent release of the virus's genetic material in the cell cytoplasm so that the replication processes take place.

Figure 2 - Entry of the virus into the host cell.

Fig. 2-A

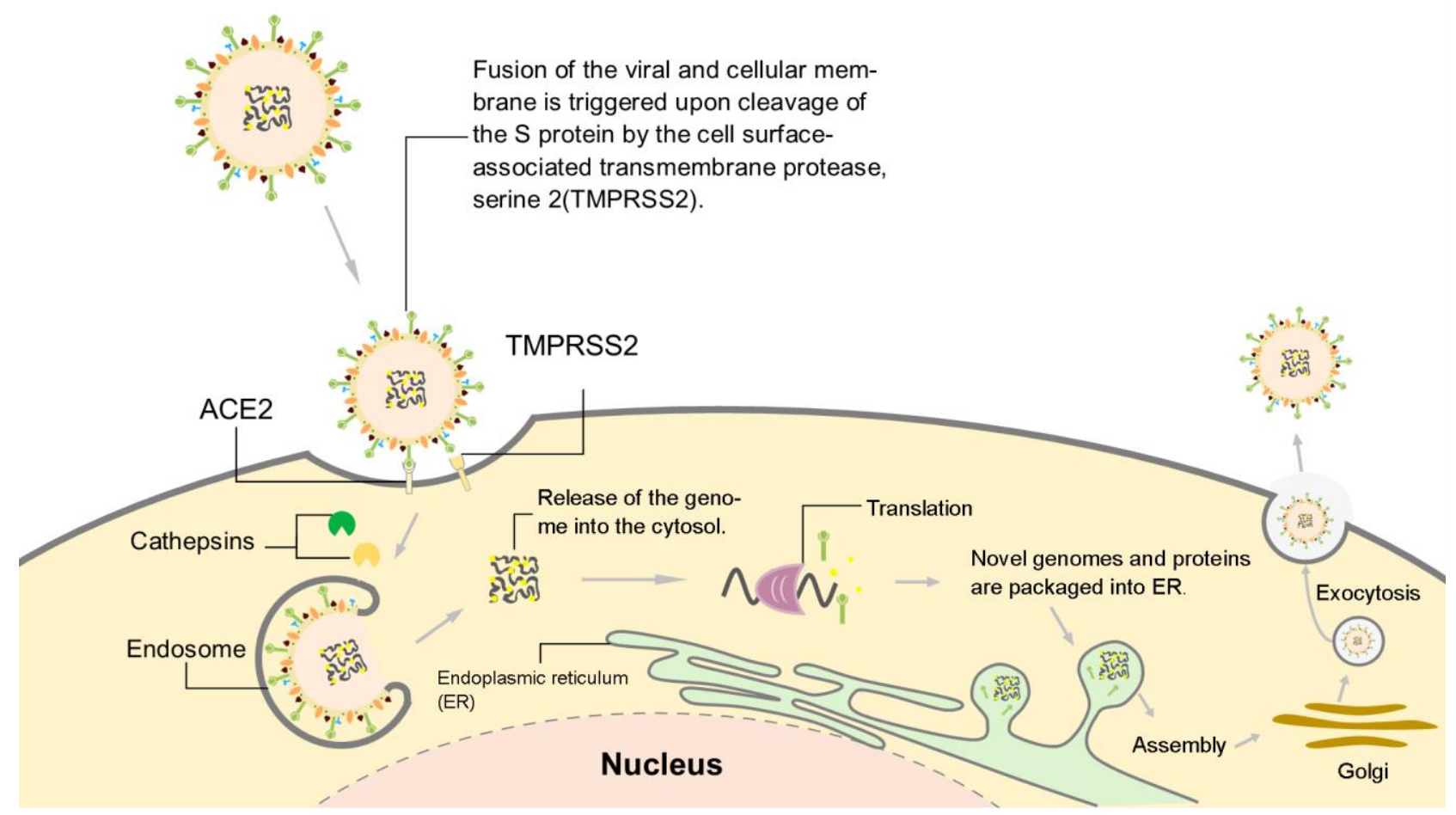

Fig. 2-B

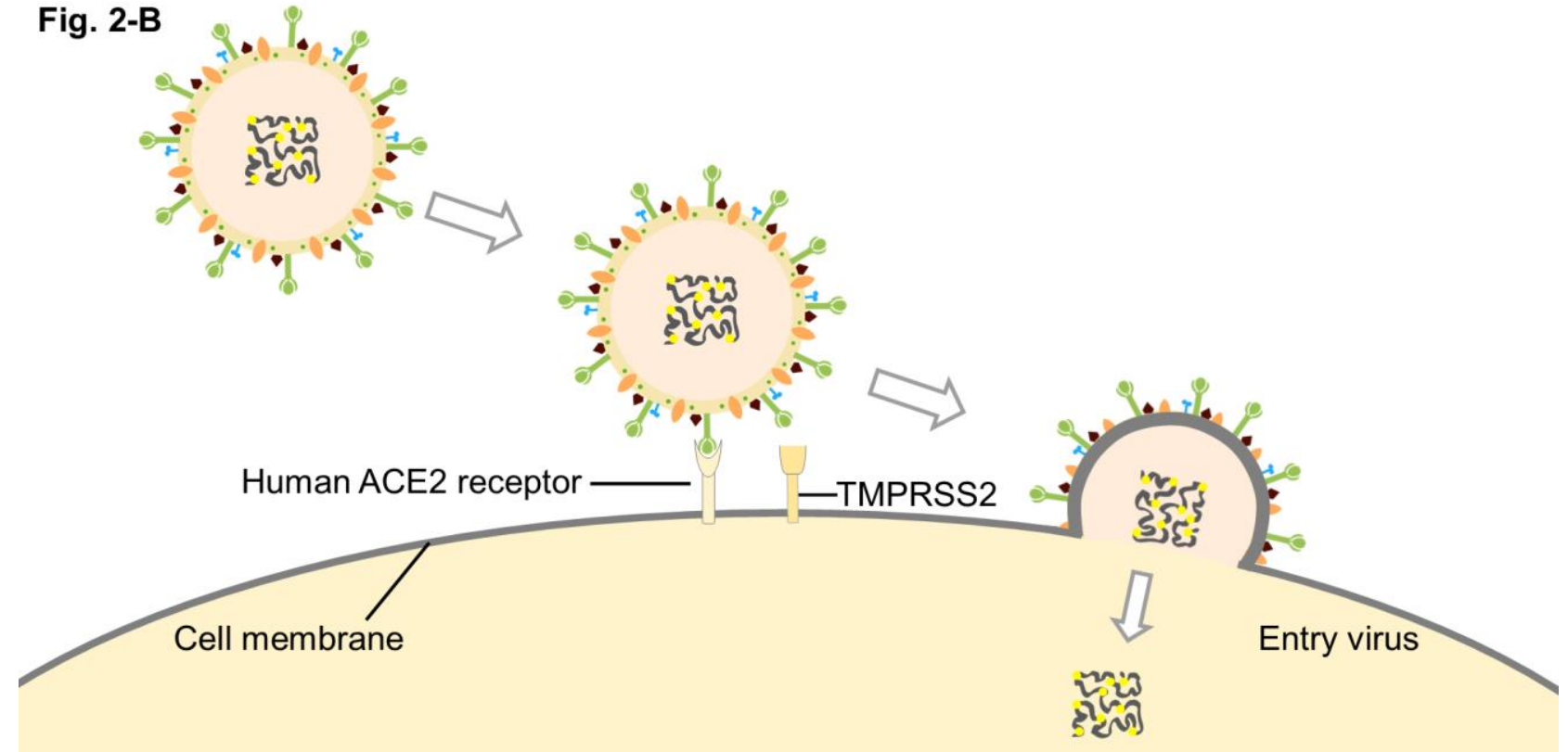

HOST CELL

Subtitle: A: By endocytosis; B: By fusion with the membrane. Source: Dantas KLS, et al., 2021. 
After viral entry and stripping, the virus's genetic material is translated into proteins. The nucleocapsid releases the single-stranded positive-polarity genomic RNA (+SSRNA), that acts as a messenger RNA (mRNA), that is, the sequence of its nucleotides can be translated directly into amino acids, which will form proteins, without the need to integrate the viral genome with the cell genome.

For this, the ORF1a and ORF1ab are translated into two polypeptides (pp1a and pp1ab), these, in turn, are cleaved by viral proteases, such as 3CLpro type chymotrypsins, also known as main protease (Mpro); among others, such as papaines. The cleavage of these polypeptides gives rise to 16 non-structural proteins (NSP; NSP1 to NSP16), fundamental for replicase-transcriptase complex (RTC) formation, that occurs in double membrane vesicles originating in the endoplasmic reticulum (ER), with high replicative enzymatic activity (GUO YR, et al., 2020; PASTRIAN SG, 2020; LI G, et al., 2020).

So far, it is known that most NSPs act in genomic replication and transcription, having enzymatic activities such as helicase, protease, methyltransferase, endoribonuclease, RNA polymerase and exoribonuclease. In RTC, subgenomic mRNAs (sgRNA) are synthesized, which encode the main structural proteins, such as $S$, $\mathrm{M}, \mathrm{E}$ and $\mathrm{N}$, in addition to the accessory protein HE. For new viral particles to be assembled, it is necessary the genetic material of the virus to be replicated so that there is a copy for each viral particle that will be released. For this, SsRNA+ serves as a template for the synthesis of ssRNA', which in turn, serves as a template for the formation of $\mathrm{SSRNA}^{+}$, which will later be transferred into the new capsids (GUO YR, et al., 2020; PASTRIAN SG, 2020; LI G, et al., 2020).

After the process of replication of the genetic material and translation of structural proteins (SP), SsRNA+ copies bind to $\mathrm{N}$ protein, forming the nucleocapsid. Structural proteins $\mathrm{S}, \mathrm{M}$ and $\mathrm{E}$, and accessory proteins encoded by sgRNAs are formed in the ER membrane, taken to the golgi complex and assembled next to the nucleocapsid, producing new viral particles. These particles are transported to the cell membrane in vesicles, thus, causing the release of new viral particles by budding: See figure 2-A (GUO YR, et al., 2020; PASTRIAN SG, 2020; LI G, et al., 2020).

\section{Immune response}

Upon entering the body, the viral particles activate the host's immune response, causing part of these particles to be phagocyted by dendritic cells (DC) and macrophages. After this process, the virions are digested inside the phagolysosomes and part of their proteins (antigens) are transferred to the major histocompatibility complex (MHC) class II, a molecule expressed mainly in antigen presenting cells (APC: such as dendritic and macrophage), and that play a fundamental role in the responses of innate and adaptive immunity by effectively stimulating the activation of $\mathrm{T}$ (helper and cytotoxic) and $\mathrm{B}$ lymphocytes, thus combining innate and adaptive immunity (LIU J, et al., 2020).

\section{Innate immune response}

For an effective response to infectious stimuli, the innate immune system expresses pattern recognition receptors (PRRs) to recognize pathogen-associated molecular patterns (PAMPs), that is, they identify foreign molecules present in microorganisms and induce the inflammatory process, with the objective to eliminate the infectious focus. The main receptors among PRRs include toll-like receptors (TLR: specialized in the recognition of lipids, lipoproteins, glycoproteins, proteins and nucleic acids of microbial origin), RIG-I-like (RLR), NOD-like (NLR), among several others (LI G, et al., 2020; AZKUR AK, et al., 2020; PERLMAN S and NETLAND J, 2009).

For SARS-CoV-19 to start the infection process, protein $S$ binds to the host cell's ACE2 receptor (pneumocytes) fusing with the cell membrane, forming an endosome where the virus enters its ssRNA ${ }^{+}$. Some receptors on endosomes cause these cells to produce cytokines, activating the host's immune and inflammatory responses. After the pneumocytes signaling the invasion, the leukocytes, mainly the phagocytes (dendritic cells and macrophages) are attracted to the site of infection and recognize the viral surface proteins, as well as their genetic material, mainly through the TLRs expressed on the leukocytes such as TLR3, TLR7, TLR8 and TLR9. 
After recognition of the viral antigens, the APCs begin to perform phagocytosis and subsequently the presentation of antigens to lymphocytes, which become activated via $T$ and $B$ cell receptors (TCR and BCR, respectively). The different interactions of antigen presentation between $D C$ /macrophages and lymphocytes can be summarized in figure 3 ( $A$ and $B, A$ and $C, A$ and $E$, respectively) (LI G, et al., 2020; AZKUR AK, et al., 2020; PERLMAN S and NETLAND J, 2009; GUO YR, et al., 2020).

This process leads to chemotaxis of circulating leukocytes with local production of transcription factors of pro-inflammatory mediators, such as nuclear factor kappa nuclear B (NFkB), activating protein (AP-1), interferon regulatory factor 3 (IRF3) and interferon regulatory factor 7 (IRF7), which are responsible for the production of inflammatory molecules, such as cytokines and chemokines (GUO YR, et al., 2020; BLAZEK K, et al., 2015).

NFkB and the transcription factor AP-1 stimulate the expression of genes that encode several proinflammatory mediators, such as TNF- $\alpha$, interleukins (IL-1, IL-6 and IL-12) and chemokines (CCL2 and CXCL8). IRF3 and IRF7 promote the production of type I interferon (INF-a and INF-b) that play an important role in antiviral responses (activation of cytotoxic lymphocytes and natural killers cells, which fight cells infected by COVs), thus, reducing the viral growth curve in early stages and inducing activation of adaptive immunity (mediated by T and B lymphocytes) (GUO YR, et al., 2020).

\section{Specific Immune Response}

Lymphocytes are essential for an effective antiviral immune response with subsequent production of antibodies, preventing future infections. T cells play a determining role in adaptive immunity against SARSCoV-2. The microenvironment produced by APCs determines the type of response played by $T$ cells. For SARS-CoV-2 it is known that auxiliary $\mathrm{T}$ lymphocytes (CD4+) act by activating natural killers (NK: induce infected cells to apoptosis), B lymphocytes (in plasmocytes: antibody-producing cells) and cytotoxic $T$ lymphocytes (CD8+: also act by inducing apoptosis of infected cells), as can be seen in Figure $\mathbf{3}$ (B, C and E) (LI X, et al., 2020; AZKUR AK, et al., 2020).

As células T CD8+ desempenham um papel vital na eliminação de SARS-CoV-2 e na progressão da doença por causar lesão aos brônquios alveolares resultantes dos estresses oxidativo e nitrosativo. As células CD8 podem ser ativadas por APCs (DC / macrófagos: Figura 3A, B), linfócitos CD4 (Figura 3C, B) e também por antígenos expressos no MHC-I de pneumócitos infectados, induzindo-os à apoptose pela secreção de perforinas e Granzimas (Figura 3D). As células NK desempenham papel semelhante às células CD8, secretando perforinas e granzimas (Figura E) (PASTRIAN SG, 2020).

By phagocyting viral particles, APCs present (via MHC-II) viral antigens for helper T lymphocytes (Figure 3A, C), which are responsible for the activation of others leukocytes (by producing several kind of cytokines), including B lymphocytes in plasma (Figure 3F) and memory (Figure 3G) cells (which are viable for months/years in the organism); plasmocytes (or plasma cells) are producers and secretors of antibodies (Figure $\mathbf{3 H}$ ), which will be directed firstly to the surface proteins of the viruses, neutralizing these molecules and signaling the phagocytosis process by opsonization of virions; it is important to note that the production of antibodies against the coronavirus is polyclonal, that is, a line of B lymphocytes will be activated for each antigenic protein (PASTRIAN SG, 2020).

Among the antibodies produced is immunoglobulin $\mathrm{M}(\lg \mathrm{M})$, which peaks around the 9th day after infection (the presence of this antibody in the plasma is related to the active form of the disease); and immunoglobulin $G(\lg G$ ) around the 2nd week (the presence of $\lg G$ in the plasma is related to biological protection against future infections). SARS-CoV-2 is known to induce the production of $\lg G$ against protein $\mathrm{N}$, found in blood serum 14 days after infection (PASTRIAN SG, 2020). An illustration of the humoral (A-C-F-H) and memory (AC-G) immune responses against COVID-19 can be seen in Figure 3 (software: Microsoft Publisher). 
Figura 3 - Summary of the innate and specific immune response against the COVID-19 virus.

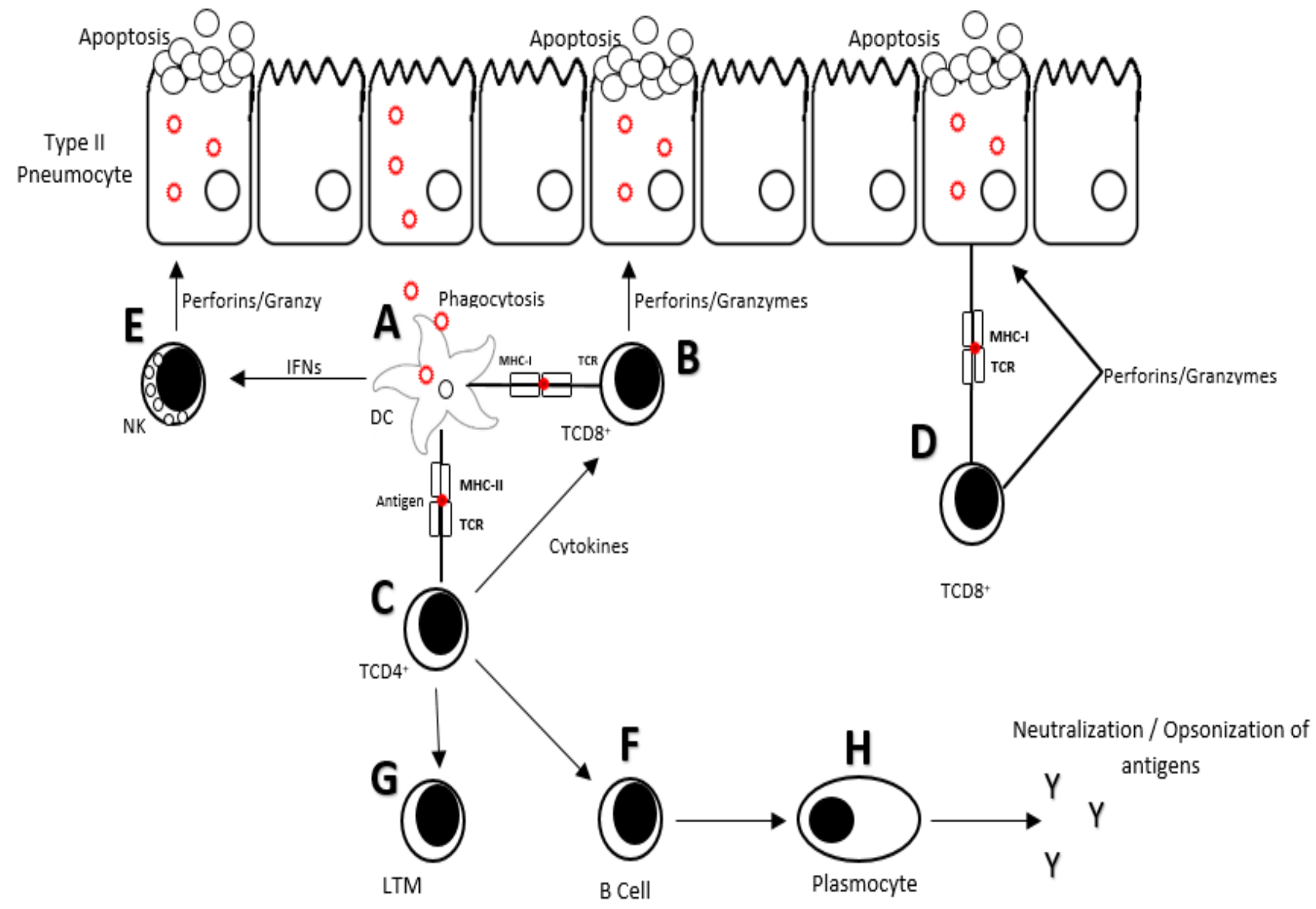

Subtitle: IFN: Interferon; DC: dendritic cell; MHC-I: major histocompatibility complex I; MHC-II: major histocompatibility complex II; TCR: T-cell receptor; LTM: memory T lymphocyte.

Source: Dantas KLS, et al., 2021.

\section{FINAL CONSIDERATIONS}

SARS-CoV-2 is already considered the biggest health problem in recent decades. This emerging virus has a high morbidity rate, causing varied signs and symptoms of COVID-19 worldwide. The high number of infected people is directly related to overcrowding in hospitals and the collapse of the health system, which directly contributes to the increase in the mortality rate. Treatment is still based on life support and amelioration of signs/symptoms, and there is still no drug with proven activity against Sars-Cov-2 in vivo.

\section{REFERENCES}

1. AZKUR AK, et al. Immune response to SARS- CoV- 2 and mechanisms of immunopathological changes in COVID19. Allergy, 2020; 75(7): 1564-1581.

2. BLAZEK K, et al. IFN- $\lambda$ resolves inflammation via suppression of neutrophil infiltration and IL- $1 \beta$ production. Journal of Experimental Medicine, 2015; 212(6): 845-853.

3. BRITTO DBLA, et al. Achados neurológicos, alterações sensoriais da função olfativa, gustativa e auditiva em pacientes com Covid-19: uma revisão literária. Revista Eletrônica Acervo Saúde, 2020; (46): 41-74.

4. CALISHER C, et al. Statement in support of the scientists, public health professionals, and medical professionals of China combatting COVID-19. The Lancet, 2020; 395(10226): 42-43.

5. CHEN Y, et al. Emerging coronaviruses: Genome structure, replication, and pathogenesis. Journal of Medical Virology, 2020; 92(4): 418-423.

6. GUO YR, et al. The origin, transmission and clinical therapies on coronavirus disease 2019 (COVID-19) outbreak - an update on the status. Military Medical Research, 2020; 7(1): 11-21. 
7. JIN Y, et al. Virology, Epidemiology, Pathogenesis, and Control of COVID-19. Viruses, 2020; 12(4): 372-389.

8. LI G, et al. Coronavirus infections and immune responses. Journal of Medical Virology, 2020; 92(4): 424-432.

9. LI X, et al. Molecular immune pathogenesis and diagnosis of COVID-19. Journal of Pharmaceutical Analysis, 2020; 10(2): 102-108.

10. LIU J, et al. Overlapping and discrete aspects of the pathology and pathogenesis of the emerging human pathogenic coronaviruses SARS- CoV, MERS- CoV, and 2019- nCoV. Journal of Medical Virology, 2020; 92(5): $491-494$.

11. PASTRIAN SG. Bases Genéticas y Moleculares del COVID-19 (SARS-CoV-2). Mecanismos de Patogénesis y de Respuesta Inmune. International journal of odontostomatology, 2020; 14(3): 331-337.

12. PERLMAN S, NETLAND J. Coronaviruses post-SARS: update on replication and pathogenesis. Nature Reviews Microbiology, 2009; 7(6): 439-450.

13. PIVA S, et al. Clinical presentation and initial management critically ill patients with severe acute respiratory syndrome coronavirus 2 (SARS-CoV-2) infection in Brescia, Italy. Journal of critical care, 2020; (58): 29-33.

14. RABAAN AA, et al. SARS-CoV-2, SARS-CoV, and MERS-COV: A comparative overview. Le infezioni in medicina, 2020; 28(2): 174-184.

15. RABI FA, et al. SARS-CoV-2 and Coronavirus Disease 2019: What We Know So Far. Pathogens, 2020; 9(3): 231245.

16. WIT E, et al. SARS and MERS: recent insights into emerging coronaviruses. Nature Reviews Microbiology, 2016; 14(8): 523-534.

17. WU F, et al. A new coronavirus associated with human respiratory disease in China. Nature, 2020; 579(7798): 265269.

18. YANG X, et al. Clinical course and outcomes of critically ill patients with SARS-CoV-2 pneumonia in Wuhan, China: a single-centered, retrospective, observational study. The Lancet Respiratory Medicine, 2020; 8(5): 475-481.

19. XAVIER AR. et al. COVID-19: manifestações clínicas e laboratoriais na infecção pelo novo coronavírus. J Bras Patol Med Lab, 2020; (56): 1-9.

20. ZHENG J. SARS-CoV-2: an Emerging Coronavirus that Causes a Global Threat. International Journal of Biological Sciences, 2020; 16(10): 1678-1685.

21. ZHOU P, et al. Fatal swine acute diarrhoea syndrome caused by an HKU2-related coronavirus of bat origin. Nature, 2018; 556(7700): 255-258.

22. ZHOU P, et al. A pneumonia outbreak associated with a new coronavirus of probable bat origin. Nature, 2020; 579(7798): 270-273. 